\title{
Infrared brazing of TiAl using Al-based braze alloys
}

\author{
R.K. Shiue ${ }^{\mathrm{a}}$, S.K. Wu ${ }^{\mathrm{b}}, *$, S.Y. Chen ${ }^{\mathrm{b}}$ \\ ${ }^{a}$ Department of Materials Science and Engineering, National Dong Hwa University, Hualien 974, Taiwan, R.O.C. \\ ${ }^{\mathrm{b}}$ Department of Materials Science and Engineering, National Taiwan University, Taipei 106, Taiwan, R.O.C.
}

Accepted 1 April 2003

\begin{abstract}
A novel approach for joining TiAl by infrared vacuum brazing using pure aluminum and BAlSi-4 filler metal has been reported in the study. For pure $\mathrm{Al}$ filler metal, the extensive presence of stable $\mathrm{TiAl}_{3}$ phase in the joint results in inherent brittleness of the bond, and it is difficult to completely remove the stable $\mathrm{TiAl}_{3}$ by heat treatment after infrared brazing. For BAlSi- 4 filler metal, the matrix of the braze alloy is mainly comprised of $\mathrm{Al}$ alloyed with $\mathrm{Si}$ and $\mathrm{Ti}$. Both Si-rich and a few Al-Fe-Si intermetallics are also observed in the braze. The transient interfacial $\mathrm{AlSi}_{3} \mathrm{Ti}_{2}$ phase is only observed in the short brazing cycle. The stable $\mathrm{Al}_{12} \mathrm{Si}_{3} \mathrm{Ti}_{5}$ phase dominates the interface between braze and TiAl substrate. For $800{ }^{\circ} \mathrm{C}$ brazing, the shear strength increases from $43.2 \mathrm{MPa}$ to 63.9 $\mathrm{MPa}$ upon increasing the brazing time. The brazed specimens are failed at the interface between $\mathrm{Al}_{12} \mathrm{Si}_{3} \mathrm{Ti}_{5}$ phase and braze alloy, and the fractured surface is rich in Si. For $900{ }^{\circ} \mathrm{C}$ brazing, the shear strength keeps about the same level upon brazing at 120 300 seconds, and its maximum shear strength is $86.2 \mathrm{MPa}$. For specimens brazed below $120 \mathrm{~s}$, the specimens are fractured at the interface between $\mathrm{Al}_{12} \mathrm{Si}_{3} \mathrm{Ti}_{5}$ and braze alloy. With increasing the brazing time, the thickness of $\mathrm{Al}_{12} \mathrm{Si}_{3} \mathrm{Ti}_{5}$ layer is increased, and the fracture mode changes from the interface into $\mathrm{Al}_{12} \mathrm{Si}_{3} \mathrm{Ti}_{5}$ layer. Further increasing the brazing time, the fractured location changes again from $\mathrm{Al}_{12} \mathrm{Si}_{3} \mathrm{Ti}_{5}$ layer into the braze alloy itself.
\end{abstract}

(C) 2003 Elsevier Science Ltd. All rights reserved.

Keywords: A. Titanium aluminide, based on TiAl; D. Microstructure; B. Bonding

\section{Introduction}

Titanium aluminides including $\mathrm{Ti}_{3} \mathrm{Al}, \mathrm{TiAl}, \mathrm{TiAl}_{2}$ and $\mathrm{TiAl}_{3}$ are featured with ordered structure, low density and high melting points. Among these alloys, TiAl is the most promising alloy due to its high specific strength, good corrosion resistance and excellent creep strength [1-10]. Considerable efforts have been focused on both alloy design and process improvements of the titanium aluminides with modified mechanical properties and corrosion resistance for structural applications [11-16]. Additionally, many manufacturing processes, such as directional solidification, superplastic forming and heattreating, have also been extensively studied [12,17-24]. A variety of TiAl components have been successfully tested in aerospace and automobile industry [7].

Joining of titanium aluminides always plays an important role in the application of such alloys. The

\footnotetext{
* Corresponding author. Tel.: + 886-2-2363-7846; fax: + 886-22363-4562.

E-mail address: skw@ccms.ntu.edu.tw (S.K.Wu).
}

bonding of titanium aluminides is more difficult to achieve compared to many other engineering alloys due to the high reactivity of TiAl and the tendency to form brittle intermetallic phase in the joint. It is reported that successful bonding can be obtained by diffusion bonding, friction welding, vacuum brazing and induction brazing $[3,25,26]$. Brazing is a good choice in bonding alloys, which are difficult to be joined by the traditional welding process. The use of silver, copper, gold, titanium and nickel base braze alloys in joining TiAl intermetallics has been reported in literatures [25-27]. In addition to the above braze alloys, aluminum based braze alloys are featured with low density and moderate corrosion resistance. The TiAl infrared brazed joint obtained using aluminum foil as filler metal has already been reported [28]. Therefore, aluminum based braze alloys could be an alternative in the vacuum brazing of TiAl.

The rapid infrared joining technique has been originally developed at the University of Cincinnati for high temperature materials [29]. Infrared vacuum brazing makes use of infrared energy generated by heating a tungsten filament in a quartz tube as the heating source 
[30-33]. The infrared rays transmitted through the quartz tube are focused on the specimen. The specimen is heated by infrared rays, and the furnace is not heated during the brazing process. Therefore, infrared brazing is a highly potential process with the characteristics of rapid thermal cycle $[29,30]$. The present work reports a new approach in joining TiAl by infrared brazing using two aluminum-based braze alloys. Both the microstructural evolution of the brazed joint and shear strength are studied in order to evaluate the relation between microstructure and joint performance.

\section{Experimental procedures}

The master alloy with the nominal composition $\mathrm{Ti}_{50} \mathrm{Al}_{50}$ (in at.\%) was prepared by vacuum arc remelting of high purity (>99.99 wt. \%) Ti rods and Al pellets. Both $\mathrm{Ti}$ rods and $\mathrm{Al}$ pellets were cleaned by $1 \mathrm{HF}-$ $15 \mathrm{HNO}_{3}-64 \mathrm{H}_{2} \mathrm{O}$ (in $\mathrm{ml}$ ) and saturated $\mathrm{NaOH}$ solution prior to vacuum arc remelting. The vacuum arc remelting was performed at least six times, and the final weight loss of the master alloy was below $0.1 \mathrm{wt} . \%$. The master alloy was homogenized subsequently at $950{ }^{\circ} \mathrm{C}$ for 100 $\mathrm{h}$. Two aluminum-based filler metals, pure $\mathrm{Al}$ and BAlSi-4 alloy tapes, were used as the brazing filler metals. Based on the AWS specification of aluminum based braze alloys, the chemical composition of BAlSi-4 alloy in weight percent was $(11-13) \mathrm{Si}, 0.3 \mathrm{Cu}, 0.1 \mathrm{Mg}$, $0.2 \mathrm{Zn}, 0.15 \mathrm{Mn}, 0.8 \mathrm{Fe}$ [34]. The solidus and liquidus

Table 1

Process variables of BAlSi-4 filler used in infrared brazing TiAl

\begin{tabular}{lll}
\hline Brazing time (s) & $800{ }^{\circ} \mathrm{C}$ & $900{ }^{\circ} \mathrm{C}$ \\
\hline 15 & $\mathrm{O}$ & $\mathrm{O}$ \\
30 & $\mathrm{O}$ & $\mathrm{O}$ \\
45 & $\mathrm{O}$ & $\mathrm{O}$ \\
60 & $\mathrm{O} / \Delta$ & $\mathrm{O} / \Delta$ \\
90 & $\mathrm{O}$ & $\mathrm{O}$ \\
120 & $\mathrm{O} / \Delta$ & $\mathrm{O} / \Delta$ \\
180 & $\mathrm{O} / \Delta$ & $\mathrm{O} / \Delta$ \\
240 & $\mathrm{O} / \Delta$ & $\mathrm{O} / \Delta$ \\
300 & $\mathrm{O} / \Delta$ & $\mathrm{O} / \Delta$ \\
\hline
\end{tabular}

O: metallographic observation specimen, $\Delta$ : shear test specimen.

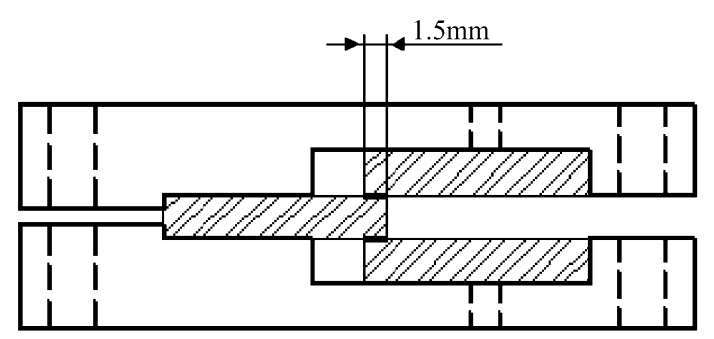

Fig. 1. A schematic diagram of the specimen used in the shear test. temperatures of this alloy are 577 and $582{ }^{\circ} \mathrm{C}$, respectively. The thickness of the braze alloy tape was $75 \mu \mathrm{m}$ throughout the experiment.

Compared with the traditional furnace brazing, infrared brazing is featured with rapid thermal cycle [29,30]. Unlike furnace brazing, higher infrared brazing temperature will do less damage to the base metal. Additionally, high brazing temperature can greatly speed up the microstructural evolution of the brazed joint. Consequently, higher brazing temperatures were chosen in the study. Infrared brazing was performed under $8 \times 10^{-5}$ mbar vacuum, and the heating rate was set at $900{ }^{\circ} \mathrm{C} / \mathrm{min}$ throughout the experiment. All specimens were preheated at $400{ }^{\circ} \mathrm{C}$ for $60 \mathrm{~s}$ before heating the specimens to the brazing temperatures. For the pure Al filler metal, the specimen was brazed at $900{ }^{\circ} \mathrm{C}$, $1000^{\circ} \mathrm{C}$ and $1100^{\circ} \mathrm{C}$ for $60-180$ s. For the BAlSi-4 filler alloy, the process variables used in brazing TiAl are summarized in Table 1.

The size of the brazed specimen was $10.0 \mathrm{~mm} \times 10.0$ $\mathrm{mm} \times 2.5 \mathrm{~mm}$. All joined surfaces were polished by $\mathrm{SiC}$ papers up to grit 1200 , and ultrasonically cleaned by acetone prior to infrared brazing. The area of filler

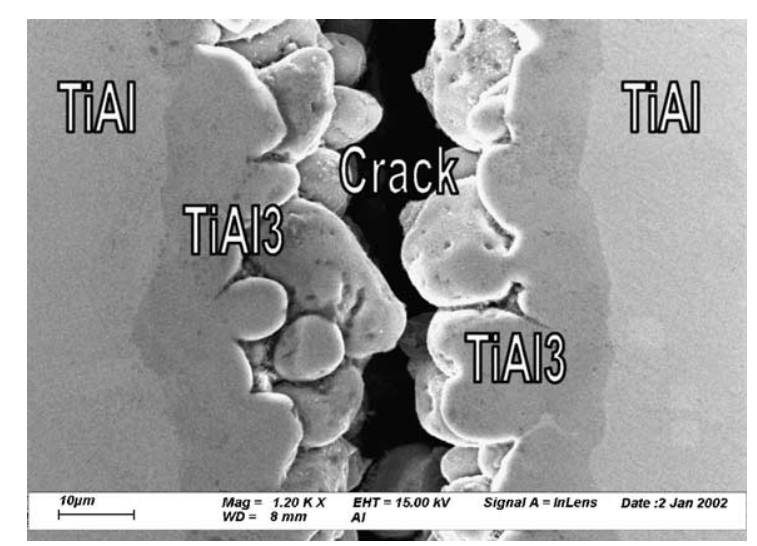

Fig. 2. The SEI of $\mathrm{TiAl} / \mathrm{Al} / \mathrm{TiAl}$ specimen brazed at $900{ }^{\circ} \mathrm{C}$ for $30 \mathrm{~s}$.

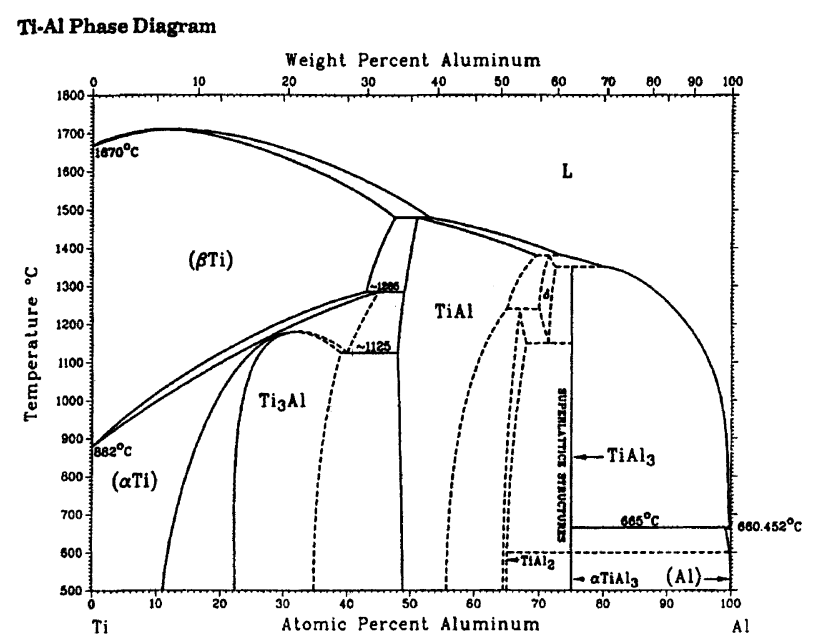

Fig. 3. Ti-Al binary alloy phase diagram [35]. 
metal was approximately the same size as that of the base metal. To enhance the absorption of infrared rays, a graphite fixture was used during brazing as described in the previous studies [30-33]. Specimens were sandwiched between two graphite plates. A thermocouple was inserted into the upper graphite plate, which was in contact with the brazed specimen. There is a time delay between the actual specimen temperature and programmer temperature, so that time compensation is necessary in the present experiment. The brazing time specified in the test is the actual specimen holding time in the experiment [30].

The brazed sample was cut by a low speed diamond saw, and was followed by a standard metallographic procedure. The cross-sections of the brazed specimens were examined using Phillips XL-30 scanning electron microscope (SEM) and a LEO 1530 field emission scanning electron microscope (FESEM) with an accelerating voltage of $15 \mathrm{kV}$. Quantitative chemical analysis was performed by using a JEOL

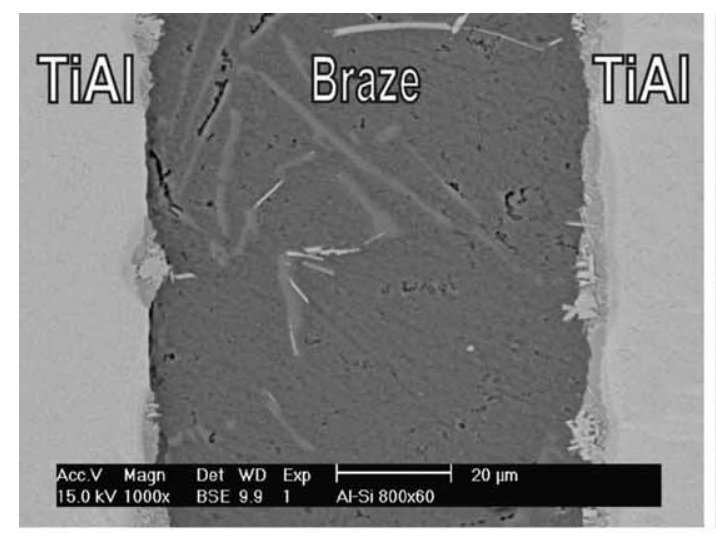

(a)

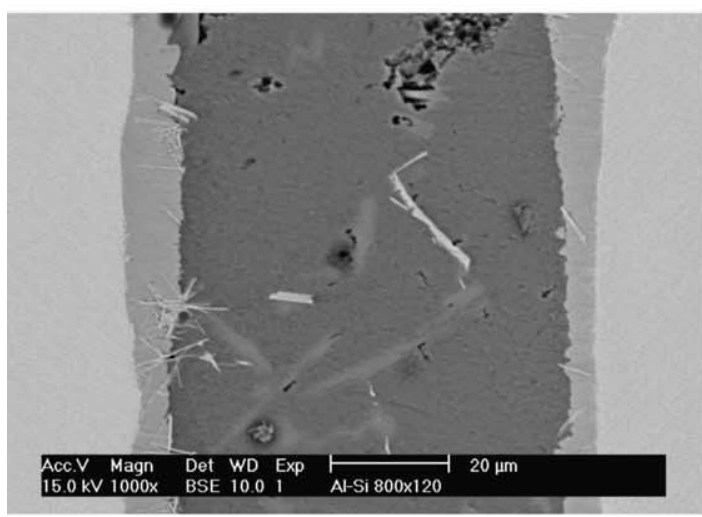

(c)

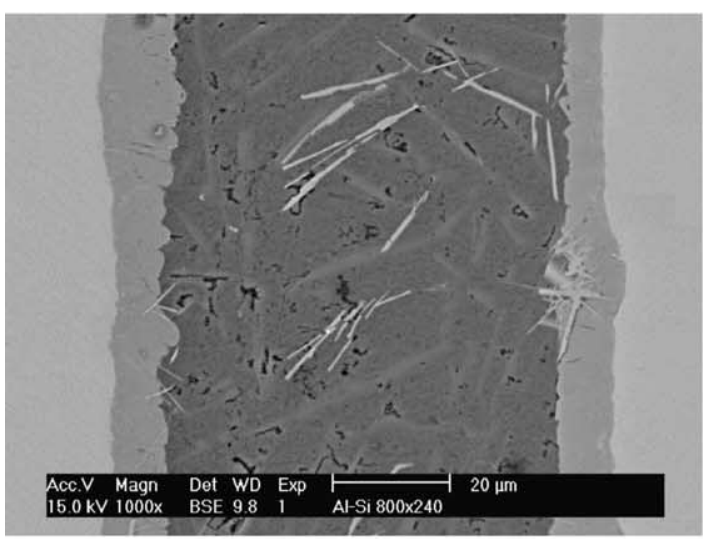

(e)

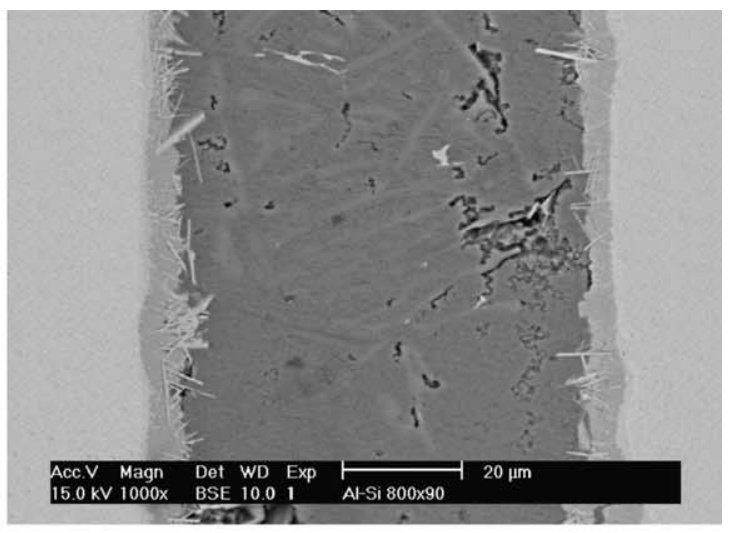

(b)

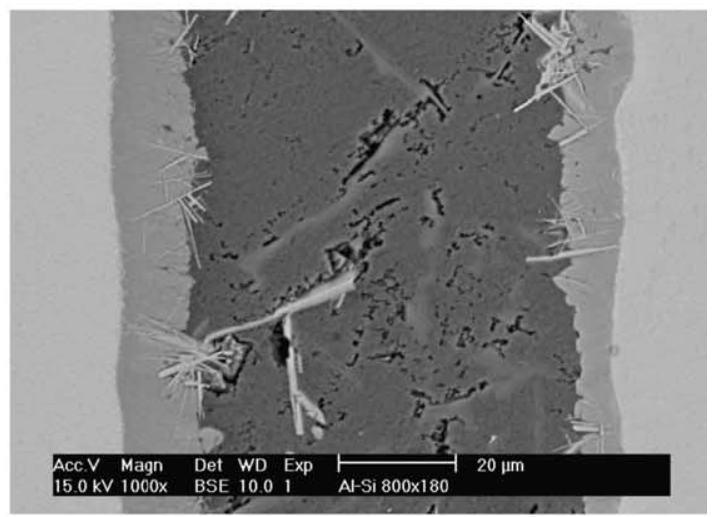

(d)

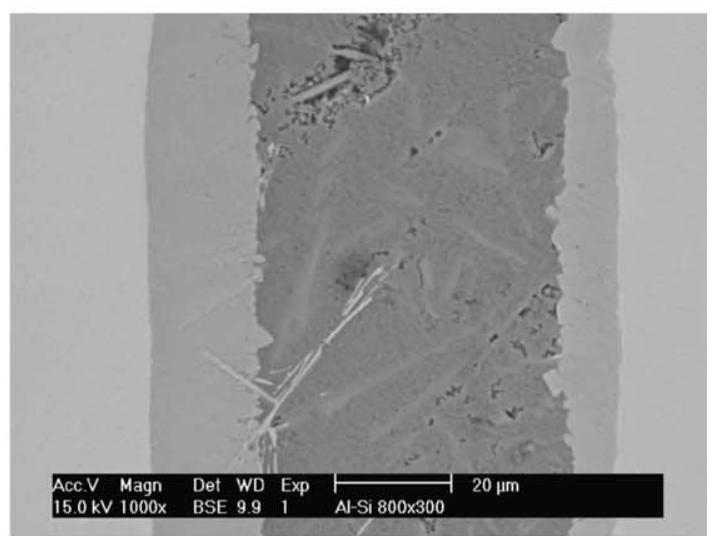

(f)

Fig. 4. The BEIs of the SEM observations for TiAl/BAlSi-4/TiAl specimen brazing at $800{ }^{\circ} \mathrm{C}$ for (a) 60 (b) 90 (c) 120 (d) 180 (e) 240 and (f) $300 \mathrm{~s}$. 
JXA-8800M electron probe microanalyzer (EPMA) equipped with a wavelength dispersive spectrometer (WDS). Its spot size was $1 \mu \mathrm{m}$, and its operation voltage was $15 \mathrm{kV}$.

Microhardness measurements were made using a microhardness tester (Akashi MVK-E II) with a load of $10 \mathrm{~g}$ and a duration time of $15 \mathrm{~s}$. The experimental data were averaged from 10 measurements of each brazing condition. A shear test was performed by the Shimadzu AG-10 universal testing machine to evaluate the bonding strength of the brazed joint. Fig. 1 shows a schematic diagram of the specimen used in the shear test. The shaded area is the TiAl base metal, and the outer part of the layout is the graphite fixture used in the infrared brazing furnace. The two $1.5 \mathrm{~mm}$ wide bold black lines in the middle of the graph represent the braze filler alloy. The brazed specimen was compressed by a universal testing machine with a constant speed of $1 \mathrm{~mm} /$ $\min$. The structure analysis of the fracture surface after the shear test was performed using a Philips PW1710 X-ray diffractometer (XRD), and $\mathrm{Cu} K_{\alpha}$ was selected as the X-ray source.

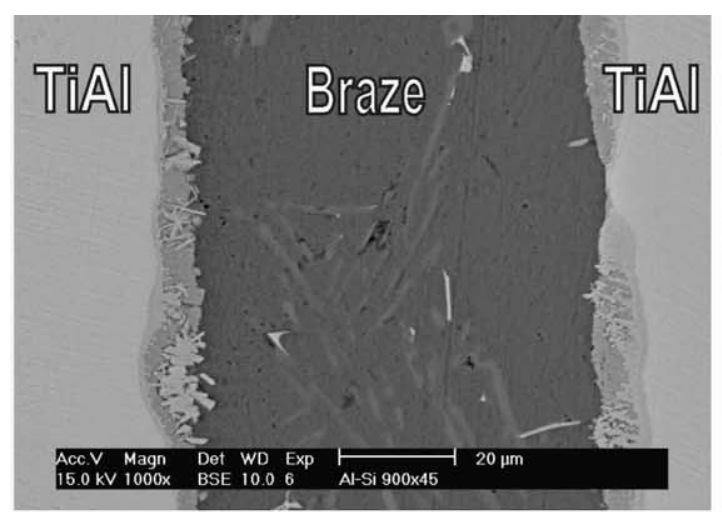

(a)

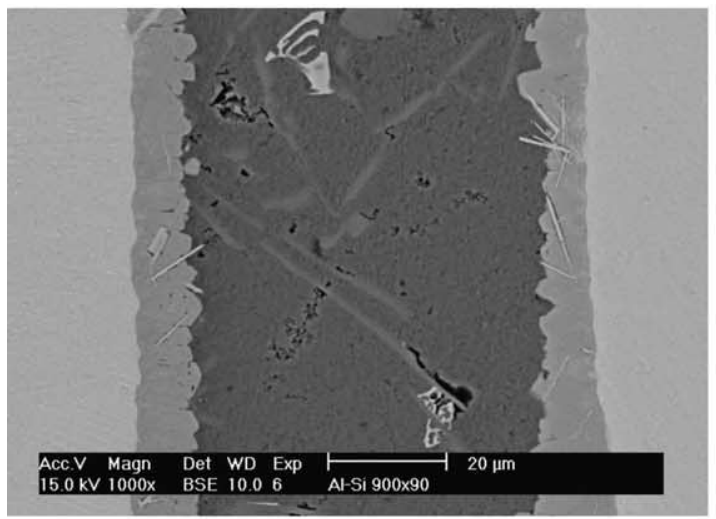

(c)

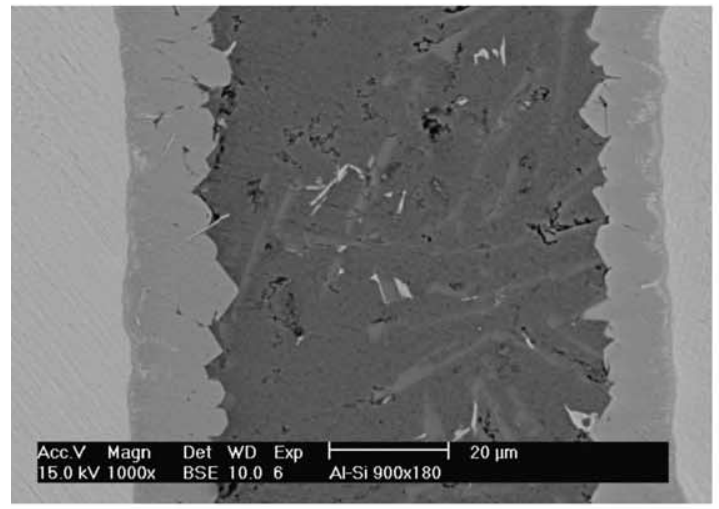

(e)

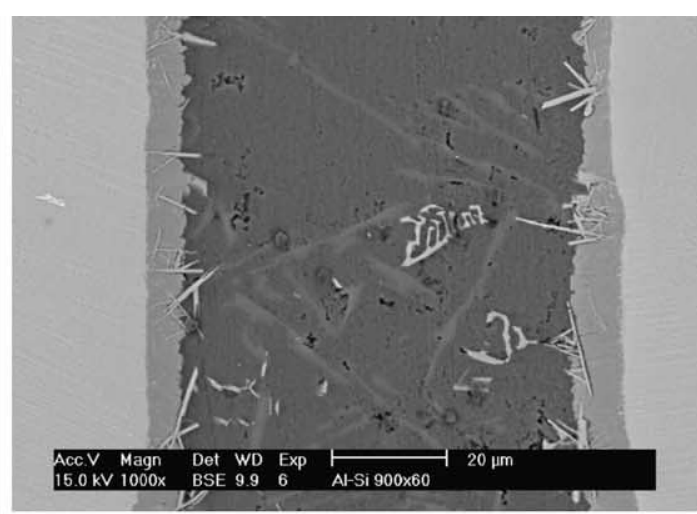

(b)

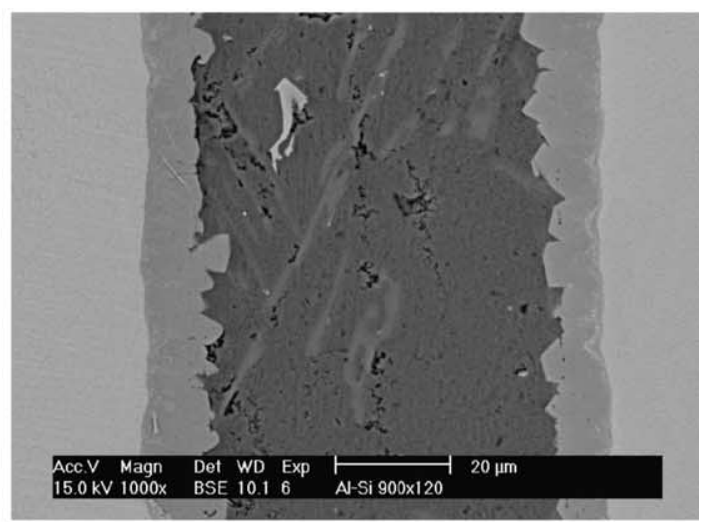

(d)

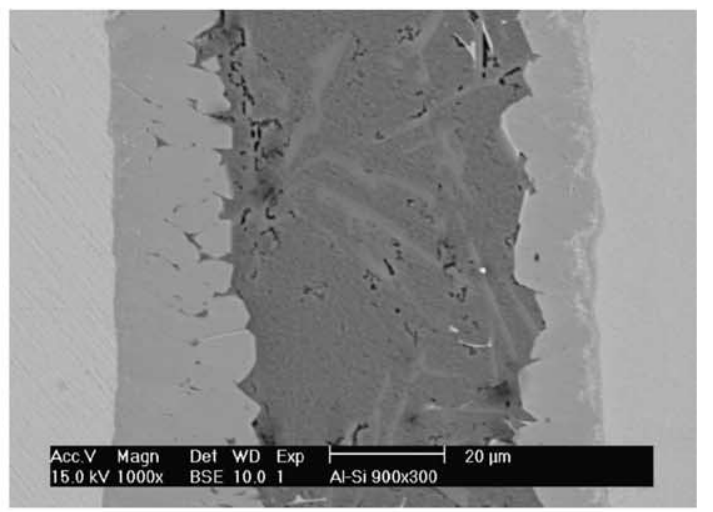

(f)

Fig. 5. The BEIs of the SEM observations for TiAl/BAlSi-4/TiAl specimen brazing at $900{ }^{\circ} \mathrm{C}$ for (a) 45 (b) 60 (c) 90 (d) 120 (e) 180 and (f) $300 \mathrm{~s}$. 


\section{Results and discussion}

\subsection{Microstructural observations of the infrared brazed TiAl/Al/TiAl}

For the pure Al filler, the bonding strength of all infrared brazed specimens was too weak to be evaluated in the experiment. All brazed joints were debonded upon cross section of specimens. Fig. 2 shows the secondary electron image (SEI) of the $\mathrm{TiAl} / \mathrm{Al} / \mathrm{TiAl}$ specimen brazed at $900{ }^{\circ} \mathrm{C}$ for 30 s. A major crack can be observed in the middle of the micrograph. The microhardness of the brazed joint is Hv 330, which is higher than that of TiAl base metal with Hv 253. According to EPMA chemical analysis, brittle $\mathrm{TiAl}_{3}$ phase is the primary phase in the joint. Fig. 3 displays the $\mathrm{Ti}-\mathrm{Al}$ binary alloy phase diagram [35]. According to the figure, it is expected that stable $\mathrm{TiAl}_{3}$ phase can be formed for specimens brazed below $1350{ }^{\circ} \mathrm{C}$. The extensive presence of stable $\mathrm{TiAl}_{3}$ phase in the joint results in inherent brittleness of the bond, and it is difficult to completely remove the stable $\mathrm{TiAl}_{3}$ by heat treatment after infrared brazing. Therefore, no further evaluation is performed in the $\mathrm{TiAl} / \mathrm{Al} / \mathrm{TiAl}$ joint.

\subsection{Microstructural evolution of the infrared brazed TiAl/BAlSi-4/TiAl}

Fig. 4(a)-(f) show the backscattered electron images (BEIs) of the SEM observations for TiAl/BAlSi-4/TiAl specimen brazed at $800^{\circ} \mathrm{C}$ for $60,90,120,180,240$ and $300 \mathrm{~s}$. Solidification shrinkage voids in the braze for all specimens can be seen, which is not unusual in brazing, since the brazing experiences a solidification process. In many brazed joints, a fraction of the joint volume will comprise residual voids that are not derived from trapped air or gas [36]. These residual voids are extremely difficult to remove because they are intrinsic to the filler metal, being caused by shrinkage upon solidification [36]

In Fig. 4, it is clearly observed that there is at least one continuous layer between BAlSi-4 alloy and TiAl substrate, and the thickness of the reaction layer is increased upon increasing the brazing time. Similar results can be obtained if the brazing temperature increases from $800{ }^{\circ} \mathrm{C}$ to $900{ }^{\circ} \mathrm{C}$ as shown in Fig. 5. It is essential to perform an EPMA chemical analysis in order to unveil the microstructural evolution of the brazed joint.

According to Fig. 5, TiAl/BAlSi-4/TiAl brazed joint at $900{ }^{\circ} \mathrm{C}$ for $45 \mathrm{~s}$ demonstrates complex interfacial reactions, so it has been chosen in the chemical analysis. Fig. 6 shows the FESEM BEI observation and EPMA chemical analysis results of $\mathrm{TiAl} / \mathrm{BAlSi}-4 / \mathrm{TiAl}$ specimens brazed at $900{ }^{\circ} \mathrm{C}$ for $45 \mathrm{~s}$. The matrix of the braze is mainly comprised of Al-rich matrix alloyed with minor $\mathrm{Si}$ and $\mathrm{Ti}$ as marked by $\mathrm{D}$, and there is a gray
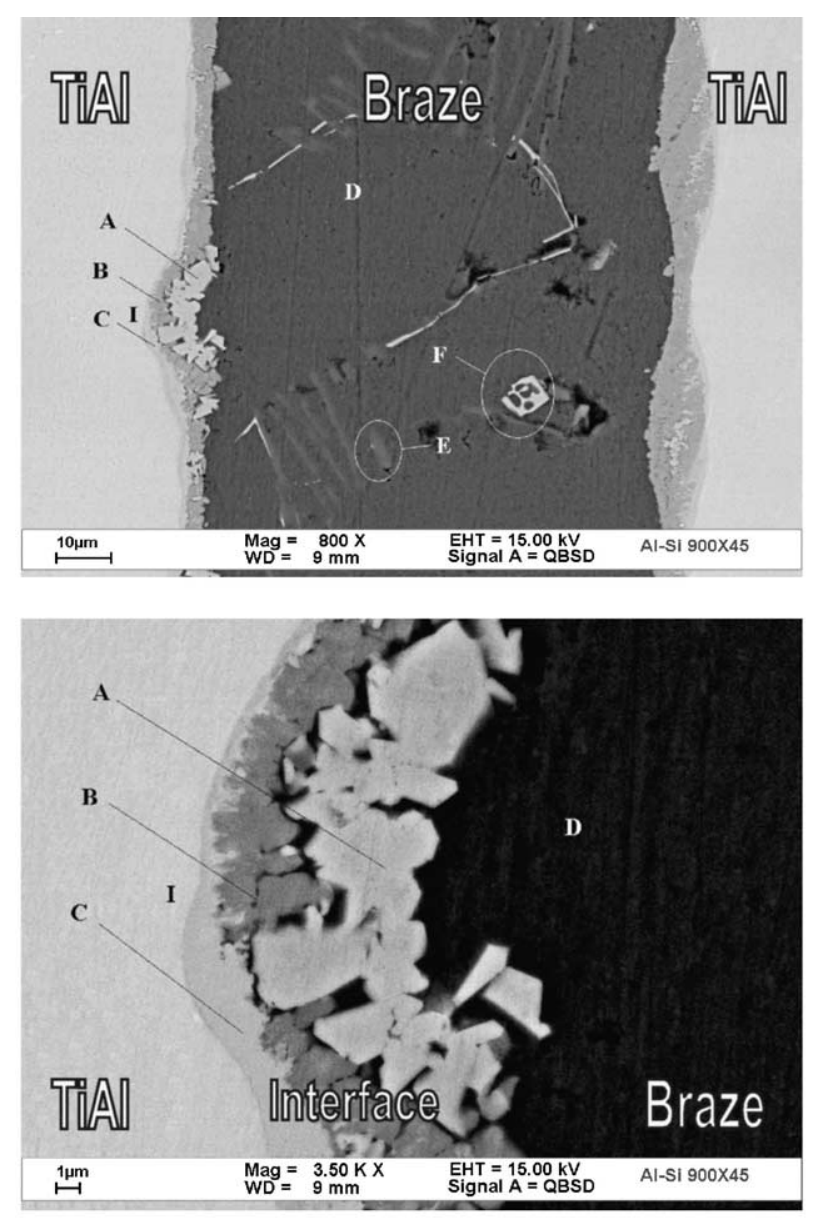

\begin{tabular}{|c|c|c|c|c|c|c|}
\hline $\mathrm{Wt} \% / \mathbf{A t} \%$ & $\mathrm{~A}$ & $\mathrm{~B}$ & $\mathrm{C}$ & $\mathrm{D}$ & $\mathrm{E}$ & $\mathrm{I}$ \\
\hline $\mathrm{Ti}$ & $46.4 / \mathbf{3 3 . 4}$ & $38.2 / \mathbf{2 5 . 9}$ & $49.2 / \mathbf{3 6 . 0}$ & $0.3 / \mathbf{0 . 2}$ & $0.2 / \mathbf{0 . 2}$ & $30.0 / 49.3$ \\
\hline $\mathrm{Al}$ & $13.6 / \mathbf{1 7 . 4}$ & $52.3 / \mathbf{6 3 . 1}$ & $11.9 / \mathbf{1 5 . 5}$ & $99.2 / \mathbf{9 9 . 3}$ & $11.2 / \mathbf{1 1 . 6}$ & $63.2 / \mathbf{4 1 . 6}$ \\
\hline $\mathrm{Si}$ & $40.0 / \mathbf{4 9 . 2}$ & $9.5 / \mathbf{1 1 . 0}$ & $38.9 / \mathbf{4 8 . 5}$ & $0.5 / \mathbf{0 . 5}$ & $88.6 / \mathbf{8 8 . 2}$ & $6.8 / \mathbf{9 . 1}$ \\
\hline $\mathrm{Phase}$ & $\mathrm{AlSi}_{3} \mathrm{Ti}_{2}$ & $\mathrm{Al}_{12} \mathrm{Si}_{3} \mathrm{Ti}_{5}$ & $\mathrm{AlSi}_{3} \mathrm{Ti}_{2}$ & $\mathrm{Al}$-rich & $\mathrm{Si}$-rich & $\mathrm{TiAl}$ \\
\hline
\end{tabular}

Fig. 6. The FESEM BEI observations and EPMA chemical analysis results of $\mathrm{TiAl} / \mathrm{BAlSi}-4 / \mathrm{TiAl}$ specimens brazed at $900{ }^{\circ} \mathrm{C}$ for $45 \mathrm{~s}$.

streak-like Si-rich phase as marked by $\mathrm{E}$ in the figure. The TiAl substrate is alloyed with $\mathrm{Si}$ as marked by I in Fig. 6. It is also observed that there are several phases at the interface between the braze alloy and TiAl base metal. According to the $\mathrm{Al}-\mathrm{Si}-\mathrm{Ti}$ ternary alloy phase diagram, the stoichiometry of both the phases $\mathrm{A}$ and $\mathrm{C}$ is very close to $\mathrm{AlSi}_{3} \mathrm{Ti}_{2}$, and the stoichiometry of phase $\mathrm{B}$ is close to $\mathrm{Al}_{12} \mathrm{Si}_{3} \mathrm{Ti}_{5}$ [37]. It is noted that $\mathrm{AlSi}_{3} \mathrm{Ti}_{2}$ at the interface is prominent only at the early stage of infrared brazing. The amount of $\mathrm{AlSi}_{3} \mathrm{Ti}_{2}$ phase at the interface is greatly decreased upon increasing either the brazing temperature or brazing time as shown in Figs. 4 and 5. If the specimen brazing at $900{ }^{\circ} \mathrm{C}$ exceeds $120 \mathrm{~s}$, $\mathrm{AlSi}_{3} \mathrm{Ti}_{2}$ phase is disappeared completely. Additionally, it is worth noting that the interfacial $\mathrm{AlSi}_{3} \mathrm{Ti}_{2}$ phase is not continuous.

Different from the $\mathrm{AlSi}_{3} \mathrm{Ti}_{2}$ phase, the continuous $\mathrm{Al}_{12} \mathrm{Si}_{3} \mathrm{Ti}_{5}$ (marked by $\mathrm{B}$ in Fig. 6) grows rapidly and 
dominates the interfacial reaction upon increasing the brazing time. Fig. 7 shows the FESEM BEI observations and EPMA chemical analysis results of $\mathrm{TiAl} /$ BAlSi-4/TiAl specimens brazed at $900{ }^{\circ} \mathrm{C}$ for $300 \mathrm{~s}$. Three phases are observed in the braze, including: Alrich matrix (marked by D), Si-rich phase (marked by E) and minor $\mathrm{Al}-\mathrm{Fe}-\mathrm{Si}$ intermetallics (marked by $\mathrm{F}$ ). It is observed that a little $\mathrm{Al}-\mathrm{Fe}-\mathrm{Si}$ phase exists in the braze after infrared brazing, and the formation of $\mathrm{Al}-\mathrm{Fe}-\mathrm{Si}$ intermetallics can be attributed to the minor $\mathrm{Fe}$ content in the BAlSi-4 braze alloy. Similar to the aforementioned result, continuous $\mathrm{Al}_{12} \mathrm{Si}_{3} \mathrm{Ti}_{5}$ phase is the stable interfacial phase in the joint as marked by B in Fig. 7. Additionally, a thin layer of $\mathrm{TiAl}_{2}$ alloyed with minor $\mathrm{Si}$ is observed as marked by $\mathrm{H}$ in Fig. 7. There is one phase marked by $\mathrm{G}$ in the figure, and any known stoichiometric
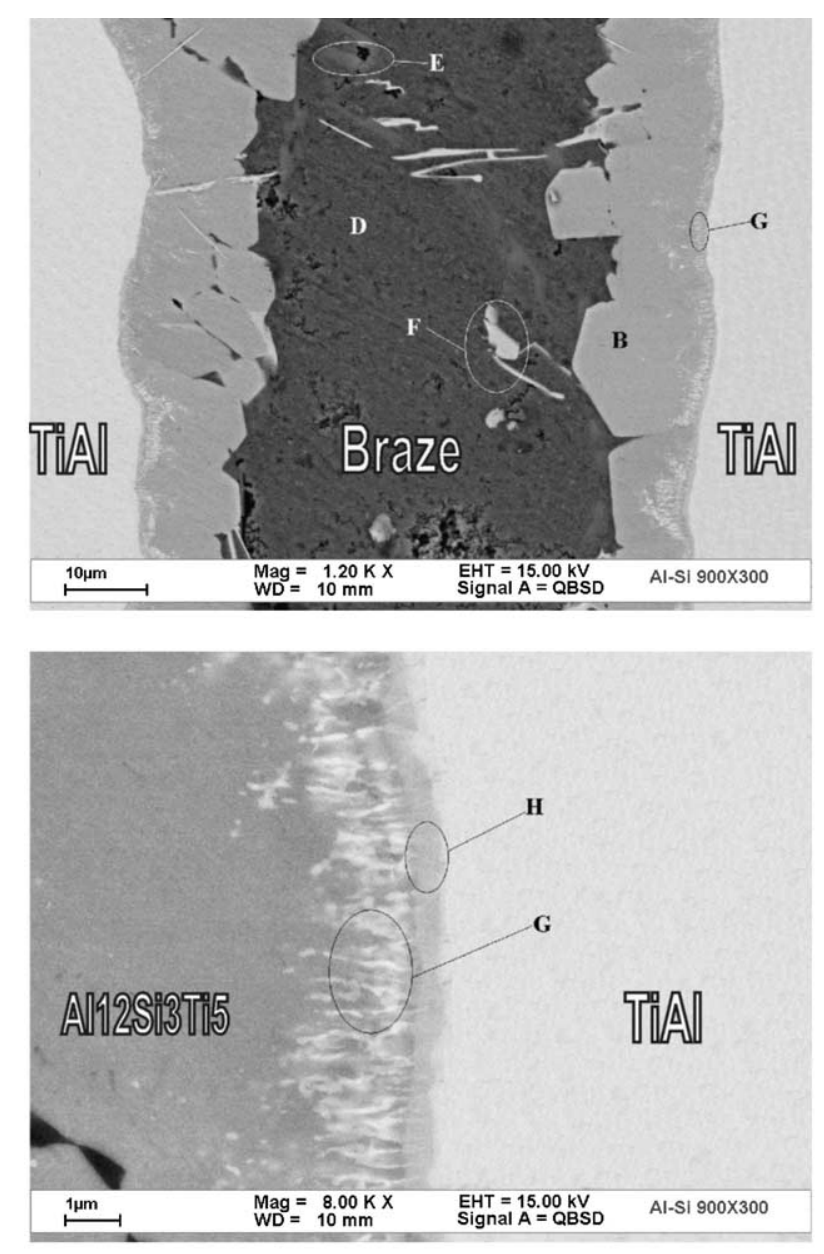

\begin{tabular}{|c|c|c|c|c|c|c|}
\hline $\mathrm{Wt} \% / \mathbf{A t} \%$ & $\mathrm{~B}$ & $\mathrm{D}$ & $\mathrm{E}$ & $\mathrm{F}$ & $\mathrm{G}$ & $\mathrm{H}$ \\
\hline $\mathrm{Ti}$ & $38.2 / \mathbf{2 5 . 9}$ & $0.3 / \mathbf{0 . 2}$ & $0.2 / \mathbf{0 . 2}$ & $0.1 / \mathbf{0 . 1}$ & $46.1 / 32.6$ & $50.5 / 36.5$ \\
\hline $\mathrm{Al}$ & $52.3 / \mathbf{6 3 . 1}$ & $99.2 / \mathbf{9 9 . 3}$ & $11.2 / \mathbf{1 1 . 6}$ & $48.4 / \mathbf{5 7 . 0}$ & $43.6 / \mathbf{5 5 . 0}$ & $48.3 / \mathbf{6 2 . 0}$ \\
\hline $\mathrm{Si}$ & $9.5 / \mathbf{1 1 . 0}$ & $0.5 / \mathbf{0 . 5}$ & $88.6 / \mathbf{8 8 . 2}$ & $24.1 / \mathbf{2 7 . 3}$ & $10.3 / \mathbf{1 2 . 4}$ & $1.2 / \mathbf{1 . 5}$ \\
\hline $\mathrm{Fe}$ & -- & -- & -- & $27.4 / \mathbf{1 5 . 6}$ & --- & --- \\
\hline Phase & $\mathrm{Al}_{12} \mathrm{Si}_{3} \mathrm{Ti}_{5}$ & $\mathrm{Al}-$-rich & Si-rich & $\mathrm{Al}-\mathrm{Fe}-\mathrm{Si}$ & --- & $\mathrm{TiAl}_{2}$ \\
\hline
\end{tabular}

Fig. 7. The FESEM BEI observations and EPMA chemical analysis results of $\mathrm{TiAl} / \mathrm{BAlSi}-4 / \mathrm{TiAl}$ specimens brazed at $900{ }^{\circ} \mathrm{C}$ for $300 \mathrm{~s}$. compounds in the ternary alloy phase diagram cannot categorize its chemical composition. It is believed that phase $\mathrm{G}$ is formed via solid-state interdiffusion between $\mathrm{Al}_{12} \mathrm{Si}_{3} \mathrm{Ti}_{5}$ and $\mathrm{TiAl}_{2}$.

Fig. 8 summarizes the EPMA chemical analysis results of various phases across the joint. The matrix of the braze alloy is mainly comprised of $\mathrm{Al}$ alloyed with minor $\mathrm{Si}$ and $\mathrm{Ti}$. Both $\mathrm{Si}$-rich and $\mathrm{Al}-\mathrm{Fe}-\mathrm{Si}$ intermetallics are observed in the braze. However, the amount of $\mathrm{Al}-\mathrm{Fe}-\mathrm{Si}$ intermetallics is very much limited due to insufficient $\mathrm{Fe}$ content in the BAlSi-4 braze filler. The initially transient interfacial $\mathrm{AlSi}_{3} \mathrm{Ti}_{2}$ phase is only observed either at lower brazing temperatures or at short brazing cycle. The $\mathrm{TiAl}_{2}$ phase alloyed with minor $\mathrm{Si}$ is observed for longer brazing time. The stable interfacial $\mathrm{Al}_{12} \mathrm{Si}_{3} \mathrm{Ti}_{5}$ phase is formed initially and grows steadily during brazing. The evaluation of these phases on bonding strength of the infrared brazed specimen will be discussed in the next section.

\subsection{Shear test of the infrared brazed TiAl/BAlSi-4/TiAl}

Fig. 9 shows the shear strength of infrared brazed specimens at various brazing conditions. For specimens infrared brazed at $800{ }^{\circ} \mathrm{C}$, the shear strength increases as the brazing time increases from 120 to $300 \mathrm{~s}$. The shear strength increases from $43.2 \mathrm{MPa}$ to $63.9 \mathrm{MPa}$ upon increasing the brazing time. Additionally, the shear strength obtained for the $800{ }^{\circ} \mathrm{C}$ sample $(60 \mathrm{~s})$ is too low to be evaluated. In contrast to the specimens brazed at $800{ }^{\circ} \mathrm{C}$, the shear strength obtained is about

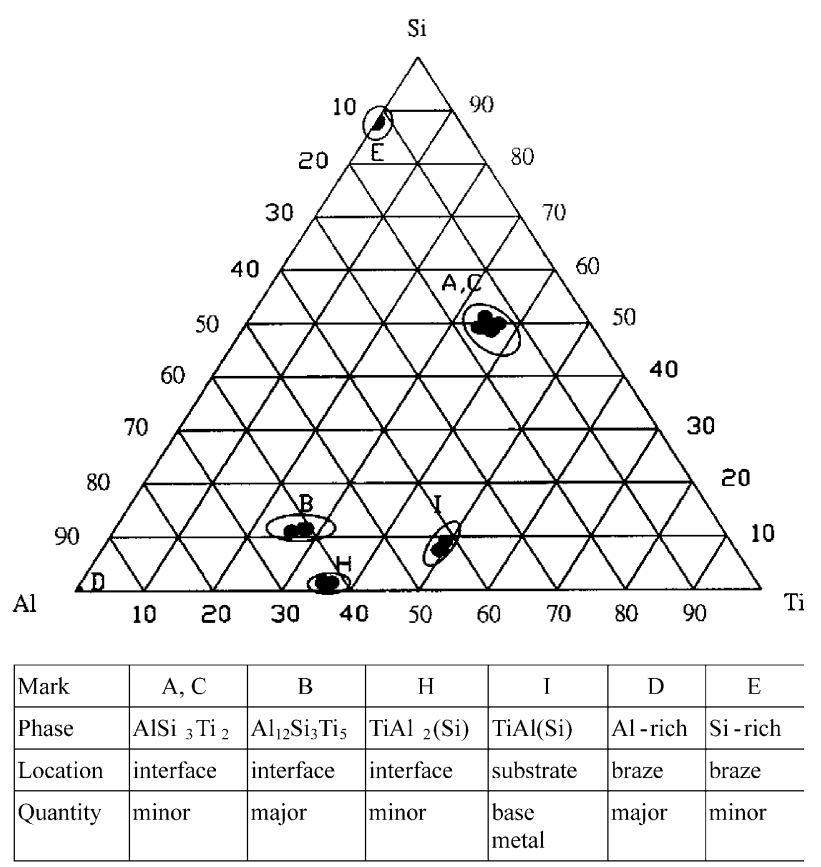

Fig. 8. Summarized EPMA chemical analysis results of various phases in the joint. 
the same level for specimens brazed at $900{ }^{\circ} \mathrm{C}$ for 120 $300 \mathrm{~s}$, and its maximum shear strength is $86.2 \mathrm{MPa}$.

Cross-sections of the above fractured specimens are mounted in an epoxy, and examined by an SEM. Since the sample was broken after shear test, only one of the broken pieces was chosen for SEM failure analysis. Fig. 10 illustrates the cross section of the shear-test of TiAl/BAlSi-4/TiAl joint infrared brazed at $800{ }^{\circ} \mathrm{C}$ for $120,180,240$ and $300 \mathrm{~s}$. There are arrows in the figure

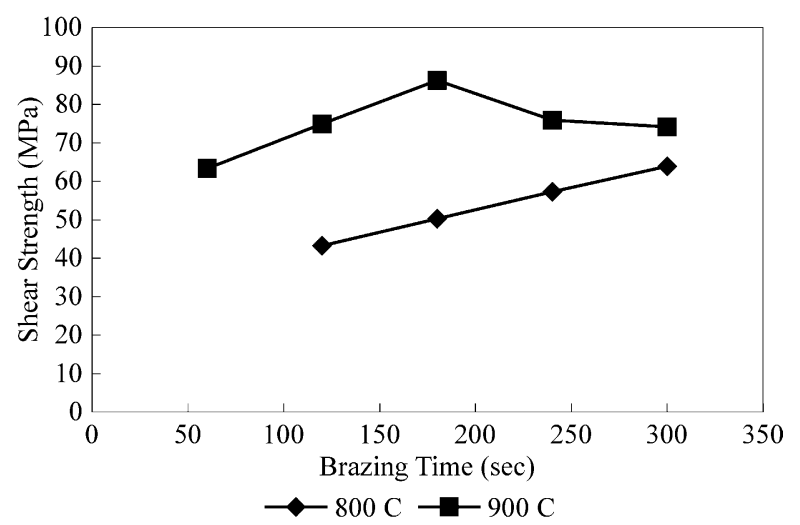

Fig. 9. The shear strength of infrared brazed specimens for various brazing conditions. indicating the location of crack. All cracks are along the interface between continuous $\mathrm{Al}_{12} \mathrm{Si}_{3} \mathrm{Ti}_{5}$ layer and the braze alloy as shown in Fig. 10. It is noted that the continuous $\mathrm{Al}_{12} \mathrm{Si}_{3} \mathrm{Ti}_{5}$ layer is not shown in Fig. 10(c) and (d), since the continuous $\mathrm{Al}_{12} \mathrm{Si}_{3} \mathrm{Ti}_{5}$ layer is located in the other part of the fractured specimen.

Fig. 11 illustrates the cross section of the shear-tested $\mathrm{TiAl} / \mathrm{BAlSi}-4 / \mathrm{TiAl}$ joint infrared brazed at $900{ }^{\circ} \mathrm{C}$ for 60, 120, 180, 240 and 300 s. Similar to Fig. 10, the fractured location shown in Fig. 11(a) is along the interface between continuous $\mathrm{Al}_{12} \mathrm{Si}_{3} \mathrm{Ti}_{5}$ layer and the braze alloy. Different from Fig. 11(a), the crack is initiated and propagated in the continuous $\mathrm{Al}_{12} \mathrm{Si}_{3} \mathrm{Ti}_{5}$ layer as displayed in Fig. 11(b) and (c). In Fig. 11(d) and (e), the cracks are located in the braze alloy itself.

There are three types of cracks observed in the experiment as summarized in Fig. 12. It is noted that a reaction layer $\left(\mathrm{Al}_{12} \mathrm{Si}_{3} \mathrm{Ti}_{5}\right)$ between the TiAl substrate and BAlSi-4 filler metal has been generated after infrared brazing as displayed in Fig. 12. Mode I crack is along the interface between continuous $\mathrm{Al}_{12} \mathrm{Si}_{3} \mathrm{Ti}_{5}$ layer and the braze alloy as shown in Figs. 10 and 11(a). Mode II cracks are initiated and propagated along the continuous $\mathrm{Al}_{12} \mathrm{Si}_{3} \mathrm{Ti}_{5}$ layer as displayed in Fig. 11(b) and (c). Finally, mode III

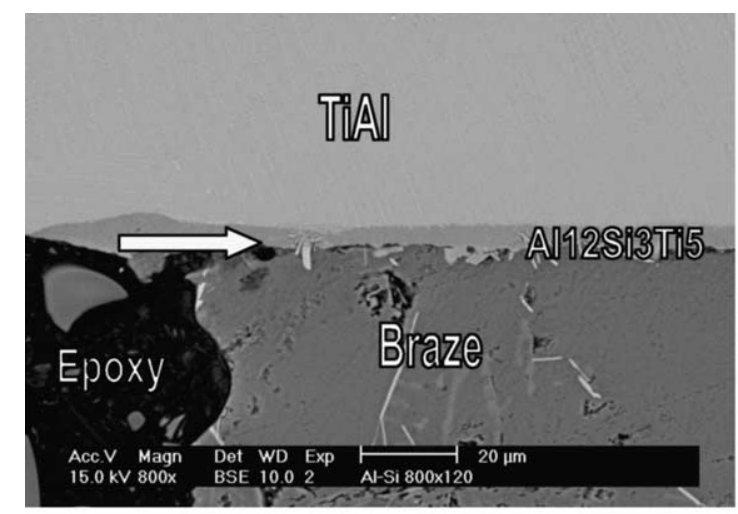

(a)

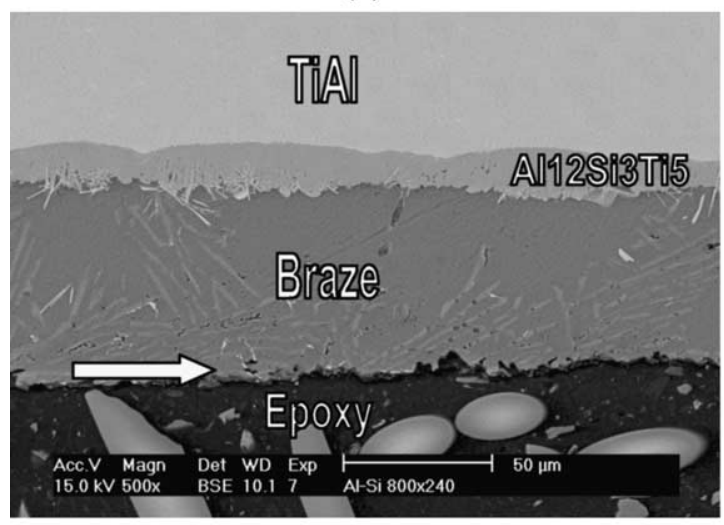

(c)

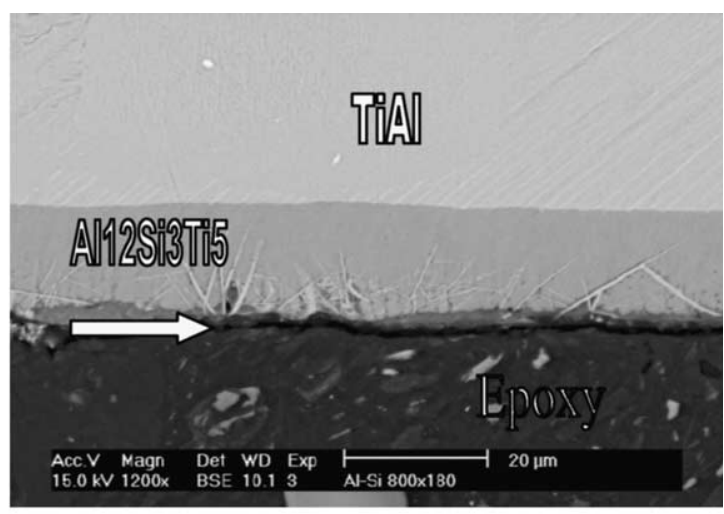

(b)

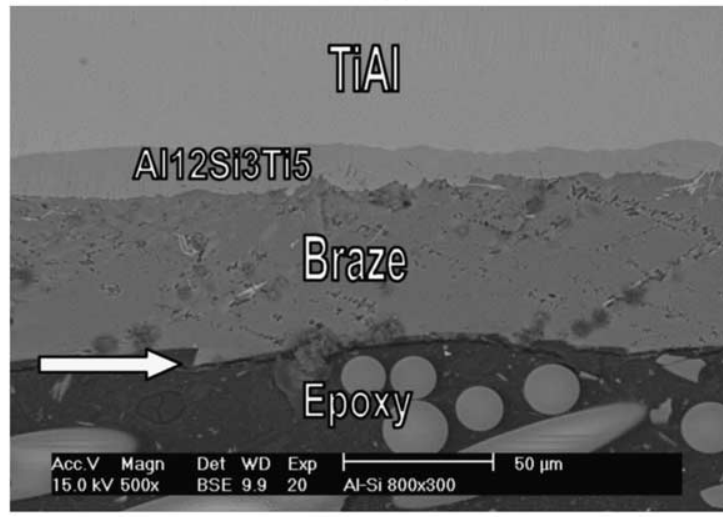

(d)

Fig. 10. Cross sectional SEM images of the TiAl/BAlSi-4/TiAl joint after shear test infrared brazing at $800{ }^{\circ} \mathrm{C}$ for (a) 120 , (b) 180 , (c) 240 and (d) $300 \mathrm{~s}$. 


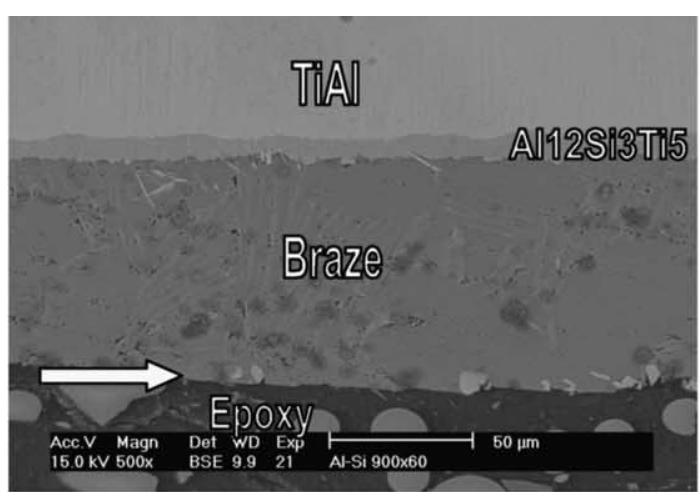

(a)

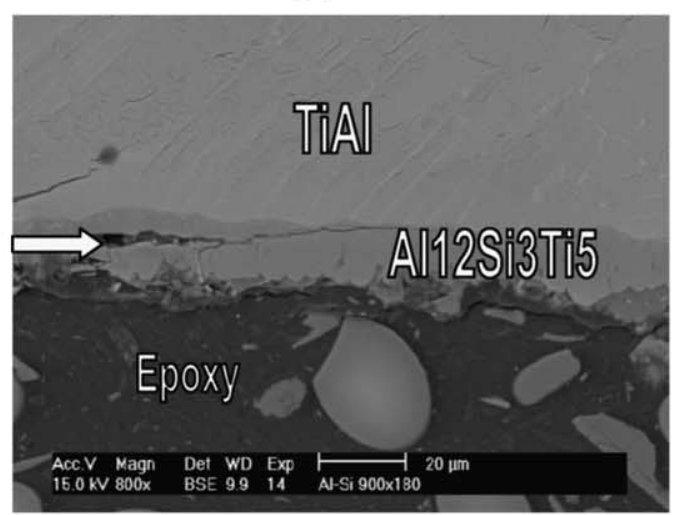

(c)

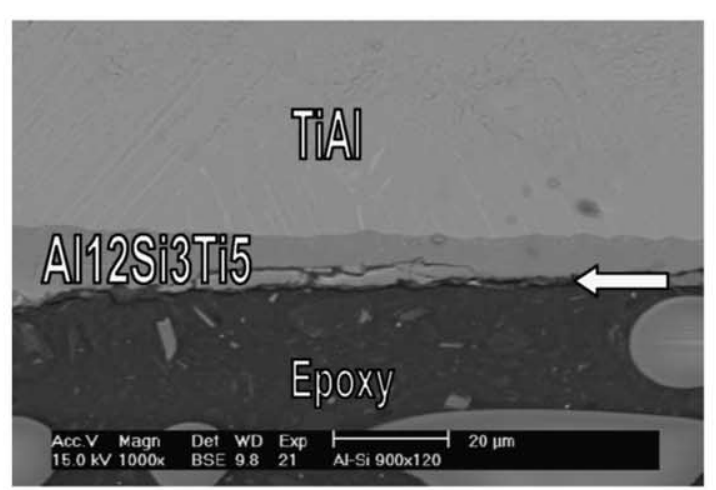

(b)

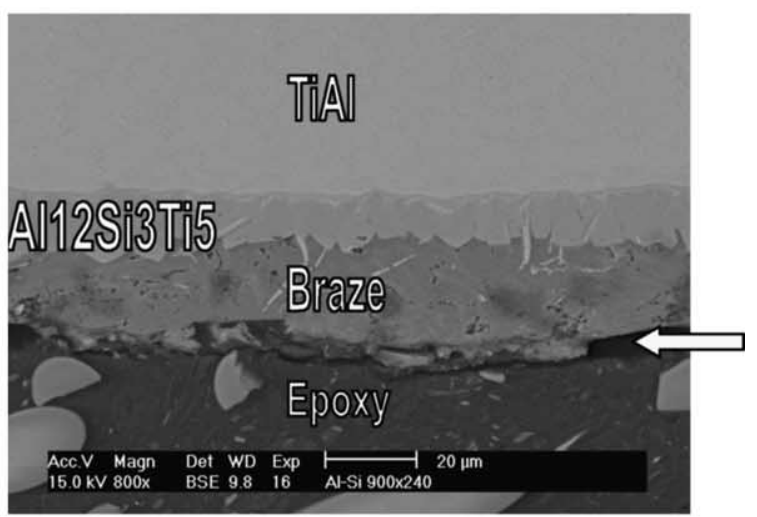

(d)

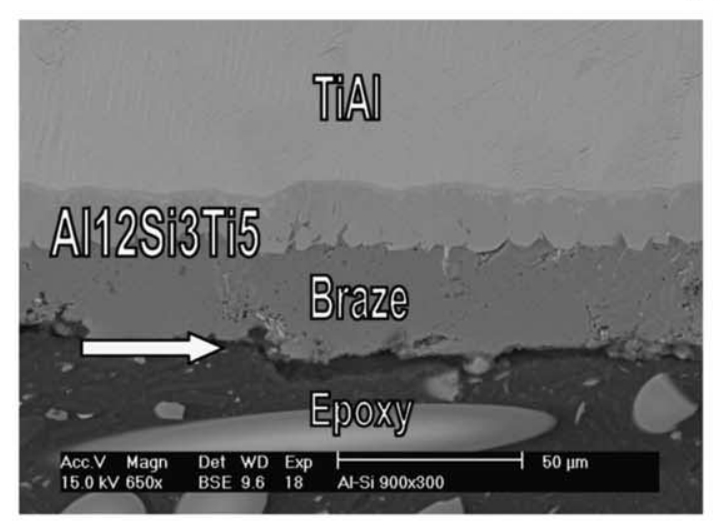

(e)

Fig. 11. Cross section al SEM images of the TiAl/BAlSi-4/TiAl joint after shear test infrared brazing at $900{ }^{\circ} \mathrm{C}$ for (a) 60 , (b) 120 , (c) 180 , (d) 240 and (e) $300 \mathrm{~s}$.

Table 2

The chemical analyses of fractured surfaces after shear test for specimens infrared brazed at $900{ }^{\circ} \mathrm{C}$

\begin{tabular}{|c|c|c|c|c|c|c|c|c|c|c|}
\hline \multirow{3}{*}{$\begin{array}{l}\text { Brazing time (s) } \\
\text { Mode (location) } \\
\%\end{array}$} & \multicolumn{2}{|l|}{60} & \multicolumn{2}{|l|}{120} & \multicolumn{2}{|l|}{180} & \multicolumn{2}{|l|}{240} & \multicolumn{2}{|l|}{300} \\
\hline & \multicolumn{2}{|c|}{ Mode I (interface) } & \multicolumn{2}{|c|}{ Mode II, $\left(\mathrm{Al}_{12} \mathrm{Si}_{3} \mathrm{Ti}_{5}\right)$} & \multicolumn{2}{|c|}{ Mode II, $\left(\mathrm{Al}_{12} \mathrm{Si}_{3} \mathrm{Ti}_{5}\right)$} & \multicolumn{2}{|c|}{ Mode III, (braze) } & \multicolumn{2}{|c|}{ Mode III, (braze) } \\
\hline & wt. \% & at. $\%$ & wt. $\%$ & at. $\%$ & wt. $\%$ & at. $\%$ & wt. $\%$ & at. $\%$ & wt. $\%$ & at. $\%$ \\
\hline $\mathrm{Al}$ & 78.3 & 79.9 & 50.4 & 61.1 & 50.8 & 61.5 & 94.1 & 94.5 & 94.2 & 94.8 \\
\hline $\mathrm{Si}$ & 18.8 & 18.4 & 10.6 & 12.3 & 10.3 & 12.0 & 5.4 & 5.2 & 5.8 & 5.2 \\
\hline $\mathrm{Ti}$ & 2.9 & 1.7 & 39.0 & 26.6 & 38.9 & 26.5 & 0.5 & 0.3 & - & - \\
\hline
\end{tabular}




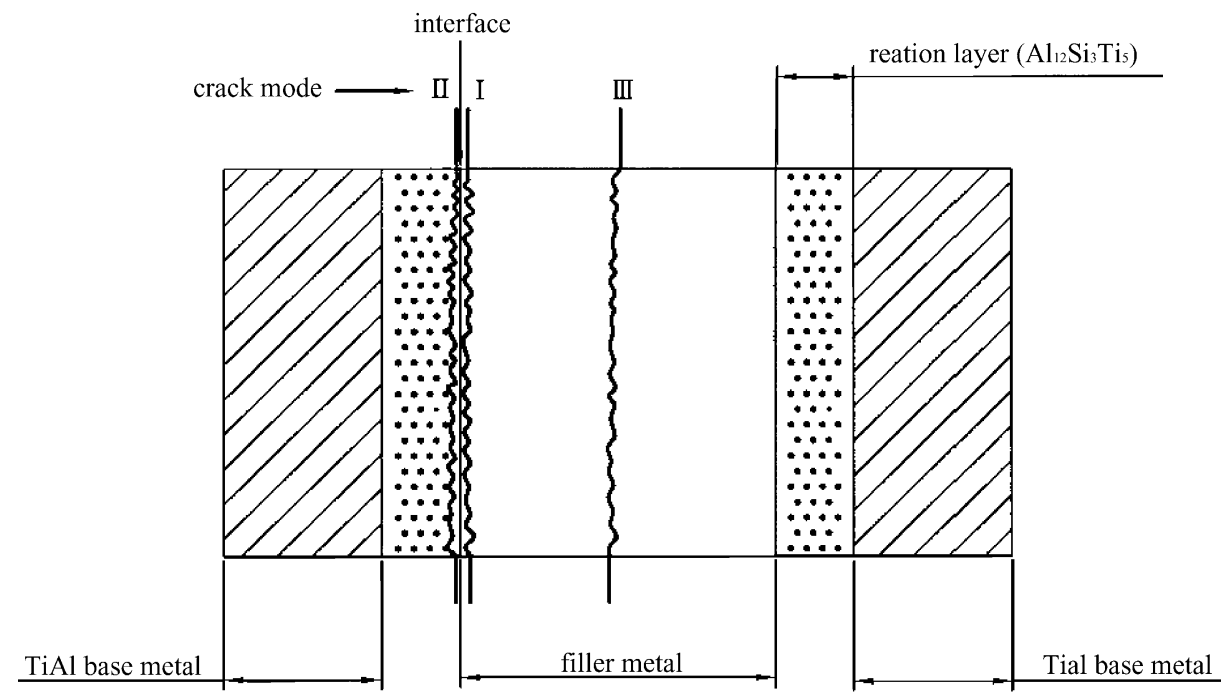

Fig. 12. Three types of failure mode in the shear test.

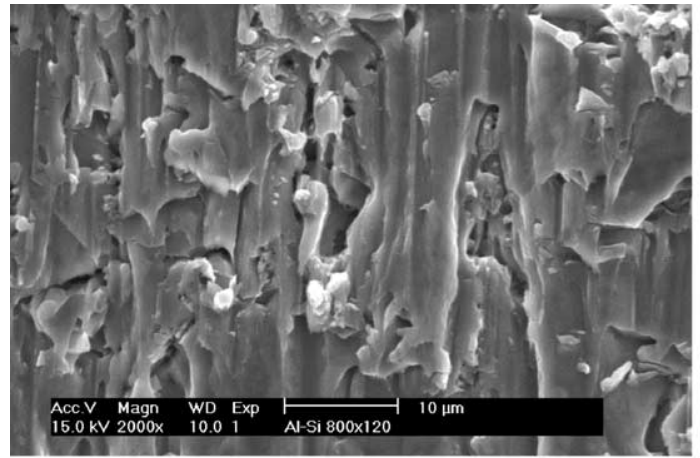

(a)

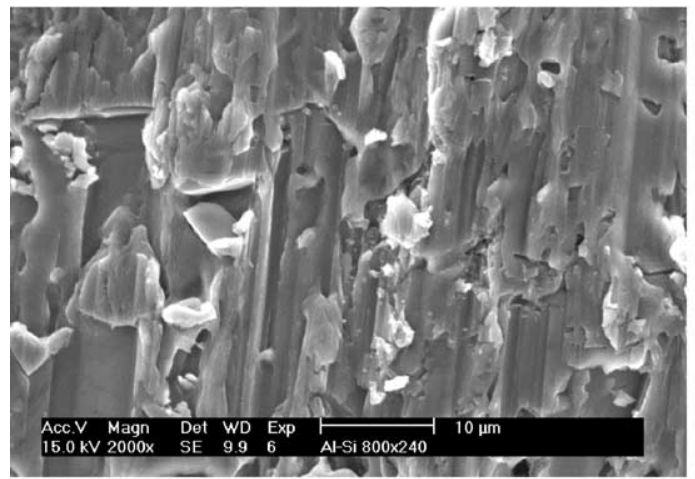

(c)

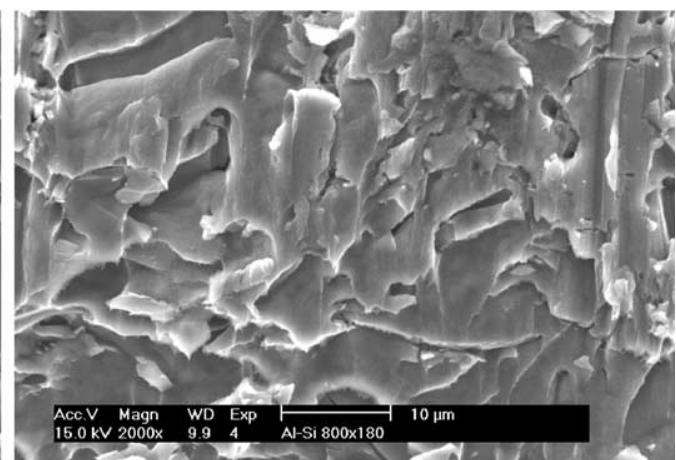

(b)

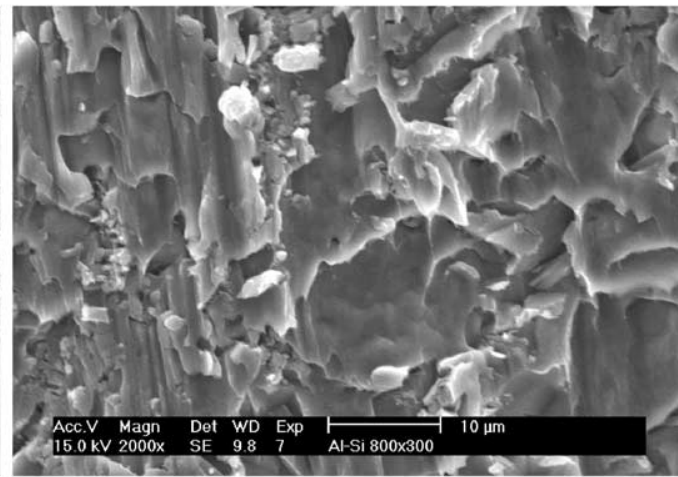

(d)

\begin{tabular}{|c|c|c|c|c|c|c|c|c|}
\hline Figure & \multicolumn{2}{|c|}{$(\mathrm{a})$} & \multicolumn{2}{c|}{$(\mathrm{b})$} & \multicolumn{2}{c|}{$(\mathrm{c})$} & \multicolumn{2}{c|}{$(\mathrm{d})$} \\
\hline $\begin{array}{c}\text { Mode } \\
\text { (Location) }\end{array}$ & \multicolumn{2}{c|}{$\begin{array}{c}\text { Mode I } \\
\text { Interface) }\end{array}$} & \multicolumn{2}{c|}{$\begin{array}{c}\text { Mode I } \\
\text { Interface) }\end{array}$} & \multicolumn{2}{c|}{$\begin{array}{c}\text { Mode I } \\
\text { (Interface) }\end{array}$} & \multicolumn{2}{c|}{$\begin{array}{c}\text { Mode I } \\
\text { (Interface) }\end{array}$} \\
\hline & wt\% $\%$ & at\% & wt\% $\%$ & at $\%$ & wt\% $\%$ & At\% & wt\% & at $\%$ \\
\hline $\mathrm{Al}$ & 88.2 & 88.6 & 86.6 & 87.0 & 86.7 & 87.1 & 86.0 & 86.5 \\
\hline $\mathrm{Si}$ & 11.8 & 11.4 & 13.4 & 13.0 & 13.3 & 12.9 & 14.0 & 13.5 \\
\hline $\mathrm{Ti}$ & --- & --- & --- & --- & --- & --- & --- & --- \\
\hline
\end{tabular}

Fig. 13. Chemical analysis and fractographs after shear test for specimens infrared brazed at $800{ }^{\circ} \mathrm{C}$ for (a) 120 , (b) 180 , (c) 240 and (d) $300 \mathrm{~s}$. 
cracks are located in the braze alloy as shown in Fig. 11(d) and (e).

Mode I cracks have the lowest shear strength among three failure modes. For all specimens brazed at $800^{\circ} \mathrm{C}$ and the specimens brazed at $900{ }^{\circ} \mathrm{C}$ below $120 \mathrm{~s}$ are featured with mode I failure. With increasing the brazing time at $900{ }^{\circ} \mathrm{C}$, the thickness of $\mathrm{Al}_{12} \mathrm{Si}_{3} \mathrm{Ti}_{5}$ layer is increased, and the fracture mode changes from mode I into mode II. The fractured location changes again from the reaction layer into the braze alloy upon further increment of the brazing time at $900{ }^{\circ} \mathrm{C}$. The shear strength of both mode II and mode III are approximately in the same level. However, the shear strength of mode I is greatly deteriorated. The X-ray analysis of the fractured surface after shear test cannot provide further information due to the insufficient diffraction pattern of the interfacial phases.

Fig. 13 shows the EDS chemical analysis and fractographs after shear test for specimens infrared brazed at $800{ }^{\circ} \mathrm{C}$ for $120,180,240$ and $300 \mathrm{~s}$. Extensive cleavage fractures are observed. According to the EDS analyses, the fractured surface is rich in Si content. Table 2 shows the chemical analysis results of the fractured surfaces after shear test for specimens infrared brazed at $900{ }^{\circ} \mathrm{C}$ for $60,120,180,240$ and $300 \mathrm{~s}$. It is obvious that all fractured surfaces of mode I failure are rich in $\mathrm{Si}$ as demonstrated in Fig. 13 and Table 2. For mode II failure, the chemical composition of the fractured surface can be identified as the $\mathrm{Al}_{12} \mathrm{Si}_{3} \mathrm{Ti}_{5}$ phase. It is consistent with the experimental result. Finally, the braze alloy is fractured in mode III failure. Compared with the chemical composition of BAlSi-4 braze alloy, the Si content is greatly depleted due to the formation of thick $\mathrm{Al}_{12} \mathrm{Si}_{3} \mathrm{Ti}_{5}$ phase at the interface.

\section{Conclusion}

1. A novel approach in joining TiAl by infrared vacuum brazing using pure aluminum and BAlSi-4 filler metal is performed in the study. For pure Al filler metal, extensive presence of the stable $\mathrm{TiAl}_{3}$ phase in the joint results in inherent brittleness of the bond. Moreover, it is difficult to completely remove the stable $\mathrm{TiAl}_{3}$ by heat treatment after infrared brazing.

2. For BAlSi-4 filler metal, the matrix of the braze alloy is mainly comprised of $\mathrm{Al}$ alloyed with minor Si and Ti. Both Si-rich and a few $\mathrm{Al}-\mathrm{Fe}-\mathrm{Si}$ intermetallics are observed in the braze. The transient interfacial $\mathrm{AlSi}_{3} \mathrm{Ti}_{2}$ phase is only observed in the short brazing cycle. The stable interfacial $\mathrm{Al}_{12} \mathrm{Si}_{3} \mathrm{Ti}_{5}$ phase forms initially and grows steadily during infrared brazing. A thin layer of $\mathrm{TiAl}_{2}$ phase alloyed with minor $\mathrm{Si}$ is also observed for longer brazing time.
3. The shear strength increases from $43.2 \mathrm{MPa}$ to 63.9 $\mathrm{MPa}$ with the increment of brazing time for specimens brazing at $800{ }^{\circ} \mathrm{C}$. The braze specimens are failed at the interface between $\mathrm{Al}_{12} \mathrm{Si}_{3} \mathrm{Ti}_{5}$ phase and braze alloy, and the fractured surface is rich in $\mathrm{Si}$ content.

4. The shear strength keeps about the same level upon brazing the specimens at $900{ }^{\circ} \mathrm{C}$ for 120 $300 \mathrm{~s}$, and its maximum shear strength is 86.2 $\mathrm{MPa}$. For specimen brazing below $120 \mathrm{~s}$, the specimen are fractured at the interface between $\mathrm{Al}_{12} \mathrm{Si}_{3} \mathrm{Ti}_{5}$ and braze alloy. With increasing the brazing time, the thickness of $\mathrm{Al}_{12} \mathrm{Si}_{3} \mathrm{Ti}_{5}$ layer increases, and the fracture mode changes from the interface into the continuous $\mathrm{Al}_{12} \mathrm{Si}_{3} \mathrm{Ti}_{5}$ layer. Upon further increasing the brazing time, the fractured location changes again from $\mathrm{Al}_{12} \mathrm{Si}_{3} \mathrm{Ti}_{5}$ layer into the braze alloy itself.

\section{Acknowledgements}

The authors gratefully acknowledge the financial support from National Science Council (NSC), Republic of China, under the grants NSC 89-2216-E002-071. EPMA analysis by Ms. Shu-Yueh Tsai in NSC Instrument Center, National Tsing Hua University, Hsinchu, Taiwan, is also gratefully acknowledged.

\section{References}

[1] Liu CT, Maziasz PJ. Intermetallics 1998;6:653.

[2] Liu CT, Schneibel JH, Maziasz PJ, Wright JL, Easton DS. Intermetallics 1996;4:429.

[3] Soboyejo WO, Lou K. Scripta Metall 1993;29:1335.

[4] Kainuma R, Fujita Y, Mitsui H, Ohnuma I, Ishida K. Intermetallics 2000;8:855.

[5] Johnson DR, Inui H, Yamaguchi M. Intermetallics 1998;6:647.

[6] Bi YJ, Abell JS. Scripta Mater 1997;37:743.

[7] Zhang WJ, Reddy BV, Deevi SC. Scripta Mater 2001;45:645.

[8] Vujic D, Li Z, Whang SH. Metall Trans 1988;19A:2445.

[9] Satry SML, Lipsitt HA. Metall Trans 1977;8A:299.

[10] Gorzel A, Sauthoff G. Intermetallics 1999;7:371.

[11] Liauo CS, Fu HC, Hsiao IC, Huang JC. Mater Sci Eng 1999; A271:275.

[12] Jung IS, Kim MC, Lee JH, Oh MH, Wee DM. Intermetallics 1999; 7:1247.

[13] Song Y, Xu DS, Yang R, Li D, Hu ZQ. Intermetallics 1998; $6: 157$.

[14] Schumacher G, Dettenwanger F, Schutze M, Hornauer U, Richter E, Wieser E, Moller W. Intermetallics 1999;7:1113.

[15] Hao YL, Xu DS, Cui YY, Yang R, Li D. Acta Mater 1999; 47:1129.

[16] Nakamura M, Nobuki M, Tanabe T, Kumagai T, Mutoh I, Abe E. Intermetallics 1998;6:637.

[17] Huang B, Deng Z, Liu Yong, Qu X, He Y. Intermetallics 2000; $8: 559$.

[18] Zhang JW, Li SQ, Zou DX, Ma WQ, Zhong ZY. Intermetallics 2000;8:699.

[19] Schuh C, Dunand DC. Acta Mater 1998;46:5663. 
[20] Nieh TG, Hsiung LM, Wadsworth J. Intermetallics 1999;7:163.

[21] Murali K, Chandra N. Acta Metall Mater 1995;43:1783.

[22] Bohn R, Klassen T, Bormann R. Intermetallics 2001;9:559.

[23] Imayev RM, Salishchev, Senkov ON, Imayev VM, Shagiev MR, Gabdullin NK, Kuznetsov AV, Froes FH. Mater Sci Eng 2001; A300:263.

[24] Xia Q, Wang JN, Wang Y, Yang J. Mater Sci Eng 2000; A300:309.

[25] Noda T, Shimizu T, Okabe M, Iikubo T. Mater Sci Eng 1997; A239-240:613.

[26] Tetsui T. Intermetallics 2001;9:253.

[27] Shiue RK, Wu SK, Chen SY. Acta Metall Mater 2003; 51:1991.

[28] Annaji S, Lin RY, Wu SK. In: Design fundamentals of high temperature composites, intermetallics and metal-ceramics systems. In: Proc 125th TMS Annual Meeting, 1996. p. 125.
[29] Blue CA, Lin RY. In: Joining and adhesion of advanced inorganic materials. MRS Symp Proc, vol. 314, 1993. p. 143.

[30] Shiue RK, Wu SK, O JM, Wang JY. Metall Mater Trans A 2000; 31A:2527.

[31] Yang TY, Wu SK, Shiue RK. Intermetallics 2001;9:341.

[32] Shiue RK, Wu SK, Hung CM. Metall Mater Trans A 2002; 33A: 1765 .

[33] Lee YL, Shiue RK, Wu SK. Intermetallics 2003;11:187.

[34] Olson DL, Siewert TA, Liu S, Edwards GR. ASM handbook, vol. 6. Materials Park (OH): ASM International; 1993. p. 938.

[35] Massalski TB. Binary alloy phase diagrams. Materials Park (OH): ASM International; 1990. p. 225-7.

[36] Humpston G, Jacobson DM. Principles of soldering and brazing. Materials Park (OH): ASM International; 1993. p. 127-8.

[37] Villars P, Prince A, Okamoto H. Handbook of ternary alloy phase diagrams. Materials Park (OH): ASM International; 1995. p. 4311-9. 